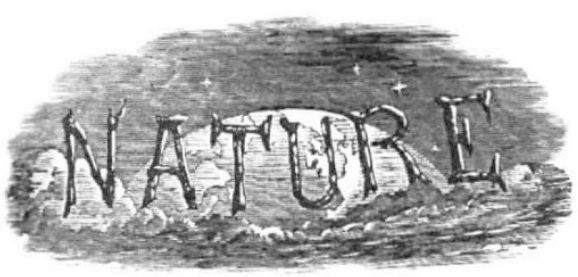

SATURDAY, SEPTEMBER I, I923.
The Revolt against the Teaching of Evolution in the United States. By Dr. W. Bateson, F.R.S. Sexual Physions. By Dr. B. Malinowski 3I4 Sexual Physiology. By F. A. E. C. • $\cdot$ 3I $^{2}$ Applied Organic Chemistry and International Trade 318 Relativity Problems . $\quad \cdot \quad \cdot \quad 319$ Geographical Influences. By Geo. G. Chisholm : $3^{20}$ Our Bookshelf

Letters to the Editor :-

Photochemical Production of Formaldehyde.-Prof. E. C. C. Baly, F.R.S., Prof. I. M. Heilbron, and W. F. Barker $\dot{\text { Air Variables.-Prof. }}$ P. C. Mahalanobis; The Writer of the Note .

Tubular Cavities in Sarsens,-C. Carus-Wilson

Barometric Pressure in High Latitudes.-L. C. W. Bonacina

Is there a Change of Wave-iength on Reflection of X-rays from Crystals ?-G. E. M. Jauncey and Carl H. Eckart

On the Structure of the Molecule. (With Diagrams.) -A. Pearse Jenkin

A Primitive Lens.-Sir R. A. S. Paget, Bart.

Baluchitherium osborni and its Relations. (Illus.

trated.). By C. Forster-Cooper

Nutrition Problems during Famine Conditions in

Russia. By Prof. Boris Slovtzov

Current Topics and Events

Our Astronomical Column

Research Items

The Liverpool Meeting of the British Association. Programmes of THE SECTIONS . Stanley Allen

The Liverpool Observatory (Bidston

The Eleventh International Physiological Congress

A Seventeenth-Century University of London. By E. D.

By W. J. Perry Hazards and Fire Extinction on Oilfields. By

H. B. Milner . . . . . .

The Greenwich Magnetic Observatory. Proposed

Removal to Holmbur y Hill

Academ c Biology

University and Educational Intelligence .

Societies and Academies .

Official Publications Received .

Technical Books

Editorial and Publishing Ofices:

MACMILLAN \& CO., LTD.,

ST. MARTIN'S STREET, LONDON, W.C. 2.

\begin{abstract}
Advertisements and business letters should be addressed to the Publishers.

Editorial communications to the Editor.
\end{abstract}

Telegraphic Address: PHUSIS, LONDON.

Telephone Number: GERRARD 8830.

\section{The Revolt against the Teaching of Evolution in the United States.}

T

HE movement in some of the Southern and

Western United States to suppress the teaching of evolution in schools and universities is an interesting and somewhat disconcerting phenomenon. As it was I who, all unwittingly, dropped the spark which started the fire, I welcome the invitation of the Editor of NATURE to comment on the consequences.

First as to my personal share in the matter. At the Toronto meeting of the American Association I was addressing a scientific gathering, mainly professional. The opportunity was unique inasmuch as the audience included most of the American geneticists, a body several hundreds strong, who have advanced that science with such extraordinary success. I therefore took occasion to emphasise the fact that though no one doubts the truth of evolution, we have as yet no satisfactory account of that particular part of the theory which is concerned with the origin of species in the strict sense. The purpose of my address was to urge my colleagues to bear this part of the problem constantly in mind, for to them the best chances of a solution are likely to occur. This theme was of course highly academic and technical. Nevertheless, to guard against misrepresentation, I added the following paragraph by the advice of a friend whose judgment proved sound, though to me such an addition looked superfluous.

"I have put before you very frankly the considerations which have made us agnostic as to the actual mode and processes of evolution. When such confessions are made the enemies of science see their chance. If we cannot declare here and now how species arose, they will obligingly offer us the solutions with which obscurantism is satisfied. Let us then proclaim in precise and unmistakable language that our faith in evolution is unshaken. Every available line of argument converges on this inevitable conclusion. The obscurantist has nothing to suggest which is worth a moment's attention. The difficulties which weigh upon the professional biologist need not trouble the layman. Our doubts are not as to the reality or truth of evolution, but as to the origin of species, a technical, almost domestic, problem. Any day that mystery may be solved. The discoveries of the last twenty-five years enable us for the first time to discuss these questions intelligently and on a basis of fact. That synthesis will follow on analysis, we do not and cannot doubt."

The season must have been a dull one, for upon this rather cold scent the more noisy newspapers went off full cry, with scare-headings "Darwin Downed," and the like. 
All this seemed foolish enough, and that practical consequences would follow was not to be expected. Nevertheless, Mr. William Jennings Bryan, with a profound knowledge of the electoral heart, saw that something could be made of it and introduced the topic into his campaign, which, though so far harmless in the great cities, has worked on the minds of simpler communities. In Kentucky a bill for suppressing all evolutionary teaching passed the House of Representatives, and was only rejected, I believe, by one vote, in the Senate of that State. In Arkansas the lower house passed a bill to the same effect almost without opposition, but the Senate threw it out. Oklahoma followed a similar course. In Florida, the House of Representatives has passed, by a two-thirds vote, a resolution forbidding any instructor "to teach or permit to be taught Atheism, agnosticism, Darwinism, or any other hypothesis that links man in blood relation to any form of life." This resolution was lately expected to pass the Senate. A melancholy case has been brought to my notice of a teacher in New Mexico who has been actually dismissed from his appointment for teaching evolution. This is said to have been done at the instigation of a revivalist who visited the district, selling Mr. Bryan's book.

The chief interest of these proceedings lies in the indications they give of what is to be expected from a genuine democracy which has thrown off authority and has begun to judge for itself on questions beyond its mental range. Those who have the capacity, let alone the knowledge and the leisure, to form independent judgments on such subjects have never been more than a mere fraction of any population. We have been passing through a period in which, for reasons not altogether clear, this numerically insignificant fraction has been able to impose its authority on the primitive crowds by whom it is surrounded. There are signs that we may be soon about to see the consequences of the recognition of "equal rights," in a public recrudescence of earlier views. In Great Britain, for example, we may witness before long the results which overtake a democracy unable to tolerate the Vaccination Act, and protecting only some $3^{8}$ per cent of its children.

As men of science we are happily not concerned to consider whether a return to Nature, as a policy, will make for collective happiness or not. Nor is it, perhaps, of prime importance that the people of Kentucky or even of "Main Street" should be rightly instructed in evolutionary philosophy. Mr. Bryan may have been quite right in telling them that it was better to know "Rock of Ages" than the ages of rocks. If we are allowed to gratify our abnormal instincts in the search for natural truth, we must be content, and we may be thankful if we are not all hanged like the Clerk of Chatham, with our ink-horns about our necks.

For the present we in Europe are fairly safe. A brief outbreak on the part of ecclesiastical authority did follow the publication of the "Origin of Species," but that is now perceived to have been a mistake. The convictions of the masses may be trusted to remain in essentials what they have always been; and I suppose that if science were to declare to-morrow that man descends from slugs or from centipedes, no episcopal lawn would be ruffled here. Unfortunately the American incidents suggest that our destinies may not much longer remain in the hands of that exalted tribunal, and that trouble may not be so far off as we have supposed.

W. BATESON.

\section{The Unity of Anthropology.}

Die Kultur der Gegenwart: ihre Entwicklung und ihre Ziele. Herausgegeben von Paul Hinneberg. Dritter Teil: Mathematik, Naturwissenschaften, Medizin. Fünfte Abteilung: Anthropologie. Unter Leitung von G. Schwalbe und E. Fischer. Pp. viii $+684+29$ Tafeln. (Leipzig und Berlin: B. G. Teubner, x923). 22s. $7 d$. ; cloth, $27 s .4 d$.

NTHROPOLOGY, the science of man-a proud A name indeed! But, alas, there is little at present but the name which stands for the unity of this science. Its subject matter it has to share with anatomy, biology, theories of heredity and variation, geology, sociology, and social psychology. Its methods are borrowed from several natural and humanistic sciences. Its aim and scope seem at first but arbitrarily claimed and loosely circumscribed by man's excessive conceit about his own importance as a central object of study. After all, man is physically but one animal species among others, while his soul has been for a long time already in the keeping of another sciencethat of psychology.

The unfortunate fact is that man has been created with a body and a soul as well, and this original sin, after having incessantly haunted the reflective mind through myth, religion, theology, and metaphysics, comes now to lay its curse on anthropology. Physical and cultural anthropology are divided by the deep rent between soul and body, matter and mind, which is no easier to bridge over in science than in the somewhat looser speculations which precede it.

An anthropologist has to be a Jack-of-all-trades as matters now are, however much he may deplore it, and he needs a good handbook of his science, wherein to store that part of his stock in trade which is not kept fresh by constant handling in his own specialist's

No. 2809 , voL. I I 2 ] 